\title{
Analysis and risk assessment of arsenic in the water sources of the cities Cuenca and Azogues, Ecuador
}

\author{
Análisis y evaluación de riesgos de arsénico en las fuentes de agua de las ciudades \\ de Cuenca y Azogues, Ecuador
}

\author{
Guillermina Pauta $^{1^{*}(\mathrm{D})}$, María Velasco ${ }^{2}$, Gabriela Vázquez ${ }^{1}$ (D), Andrea Abril ${ }^{1}$ (D), \\ Santiago Torres ${ }^{3}$ \\ ${ }^{1}$ Departamento de Ingeniería Civil, Universidad de Cuenca, Cuenca, Ecuador. \\ ${ }^{2}$ Instituto Ecuatoriano de Seguridad Social, Cuenca, Ecuador. \\ ${ }^{3}$ Facultad de Ciencias Agropecuarias, Universidad de Cuenca, Cuenca, Ecuador. \\ * Corresponding author: guillermina.pauta@ucuenca.edu.ec \\ Reception date: June 29, 2021 - Acceptance date: August 3, 2021
}

\begin{abstract}
Arsenic (As) is a toxic element present in the environment posing a threat to consumers health. To identify the arsenic content in rivers, páramos, and wells in the city of Cuenca, and in rivers in the city of Azogues, two monitoring campaigns in the period August-November 2017 were conducted, respectively during a low and high flow hydrological period. The measurements encompassed physicochemical quality indicators such as $\mathrm{pH}$, color, turbidity, and conductivity. Results show that the páramos and wells are free of As, while this toxic substance is present in surface water with higher levels in periods of high flow. A significant association between the concentration of As and the $\mathrm{pH}$ of river water was found. The risk of chronic toxicity from consumption is almost non-existent because the observed As levels exceed only exceptionally the permissible limit established by the Ecuadorian TULSMA (Unified Text of Secondary Environmental Legislation) regulation. The presence of As in surface water is the result of anthropological activities such as the use of pesticides. A permanent monitoring of the quality of water resources for human consumption is necessary, particularly in the rainy season, due to the diffuse and difficult to control pollution processes.
\end{abstract}

Keywords: Arsenic, water sources, river, groundwater, páramo, chronic toxicity.

\section{RESUMEN}

El arsénico (As) es un elemento tóxico presente en el medio ambiente que representa una amenaza para la salud de los consumidores. Para identificar el contenido de arsénico en ríos, páramos y pozos de la ciudad de Cuenca, y en ríos de la ciudad de Azogues, se realizaron dos campañas de monitoreo en el período agosto-noviembre de 2017, durante un período hidrológico de bajo y alto caudal, respectivamente. Las mediciones abarcaron indicadores de calidad fisicoquímica como $\mathrm{pH}$, color, turbidez y conductividad. Los resultados muestran que los páramos y pozos están libres de As, mientras que esta sustancia tóxica está presente en aguas superficiales con niveles más altos en períodos de alto caudal. Se encontró una asociación significativa entre la concentración de As y el pH del agua del río. El riesgo de toxicidad crónica por consumo es casi inexistente porque los niveles de As observados superan solo excepcionalmente el límite permisible establecido por el reglamento ecuatoriano TULSMA (Texto Unificado de Legislación Ambiental Secundaria). La presencia de As en aguas superficiales es el resultado de actividades antropológicas como el uso de pesticidas. Es necesario un monitoreo permanente de la calidad de los recursos hídricos para consumo humano, particularmente en la época de lluvias, debido a los procesos de contaminación difusos y difíciles de controlar.

Palabras clave: Arsénico, fuentes de agua, río, agua subterránea, páramo, toxicidad crónica.

\section{INTRODUCTION}

\subsection{Antecedents}

Long-term consumption of As contaminated water is harmful (Lillo, 2008) and can cause distinct types of cancer, premature birth, diabetes, and adverse effects on the skin, nervous system and liver (Moreno, 2003; Ng, Wang, \& Shraim, 2003). Sources of As are natural contamination of geological (Salomón, Guamán, Rubio, Galárraga, \& Abraham, 2008) and/or anthropogenic origins such as mining, agriculture, and industry. The quality of water supply is a concern since supplies come 
from surface bodies and underground reserves. Arsenic disturbs the ecosystem; it is a carcinogenic substance classified by the WHO (2011) as one of the ten most dangerous. The TULSMA regulation sets maximum limits for the main uses of water, and the Ecuadorian Technical Standard INEN (1108) defined $10 \mu \mathrm{g}$ As/L as the maximum allowable concentration in drinking water. The presence of As in water supply should be monitored (Mañay, Pistón, Cáceres, Pizzorno, \& Bühl, 2019) especially in rural environments, where the chemical quality can be seriously compromised by the existence of toxic substances, such as pesticides. IARC (2018) classifies As in group 1 of carcinogenic substances, and it is considered a public health problem that must be controlled to ensure safe water consumption (Carabantes $\&$ De Fernicola, 2003). The results of this research will be transferred to the water managers and will be used for the implementation of public policies aimed at protecting the health of the population.

\subsection{Fundamentals and bibliographic review}

Origin, entry routes, and levels of As

Naturally occurring As can affect large areas, whereas anthropogenic contamination is in general limited in areal extent. According to Lillo (2008) and Delgado, Medina, Vega, Carretero, \& Pardo (2009) is natural contamination of aquifers not governed by common geological/hydrogeological models. Arsenic is a chemical element that man neither creates nor destroys but introduces into the environment, altering the chemical and biochemical form in which it is found (Moreno, 2003). Human exposure is through the consumption of drinking water, although diet (ELIKA, 2013) and inhalation may contribute as well. In areas with arsenical waters, vegetables and livestock are also affected (Galindo, Fernández, Parada, \& Gimeno, 2005).

The highest levels of As have been recorded in groundwater in several countries, exceeding the WHO 2018 guideline of $10 \mu \mathrm{g} \mathrm{As} / \mathrm{L}$ for drinking water, and aquifers of different depths and under both reducing and oxidizing conditions (Lillo, 2008; Mayorga, 2013). It occurs in organic and inorganic form, the latter being highly toxic and carcinogenic, while in organic form As is less toxic since it is more easily excreted, but tends to accumulate in tissues and organs producing chronic toxicity (ELIKA, 2013; Ramírez, 2013).

\section{Forms of As}

The oxidized forms dominate in surface water and the reduced more toxic forms in subterranean aquifers (Bundschub, Pérez, \& Litter, 2008). The main mineral of arsenic is FeAsS (arsenopyrite) although it can occur in other metallic arsenites forms (González-Valdéz et al., 2011). In surface and groundwater, the oxidation states are commonly $\mathrm{As}^{+5}$ and $\mathrm{As}^{+3}$ and less frequently $\mathrm{As}^{0}$ and $\mathrm{As}^{-3}$ (WHO, 2011; Souza, Borges, Braga, Veloso, \& Matos, 2019). Arsenite $\left(\mathrm{As}^{+3}\right)$ is found in groundwater with a $\mathrm{pH}$ of 5 to 9 and arsenate $\left(\mathrm{As}^{+5}\right)$ in surface waters with high oxygen levels as $\mathrm{H}_{3} \mathrm{AsO}_{4}$ in the $\mathrm{pH}$ range 2 to 13 (Shi, 2004). In well-oxygenated natural waters, the most abundant form is soluble arsenate, more thermodynamically stable than arsenite (Genc, Tjell, McConchie, \& Schuilling, 2003; Castro, 2004).

\section{Factors determining the mobilization of As in groundwater}

The soluble species of As in a natural environment are controlled by the combination of several factors such as:

- The adsorption and desorption conditions on the surface of the minerals. Hydroxy groups on the surface of certain minerals and reactive adsorption sites are more abundant, particularly on iron, aluminum, and magnesium oxides and hydroxides possessing a strong affinity for $\mathrm{As}^{+5}$. Under moderately reducing conditions, the solubility of As can be conditioned by the dissolution and/or desorption of oxyhydroxides (Mayorga, 2013). The reduction of the specific surface and the charge in the solid phase of oxides and hydroxides of $\mathrm{Fe}$ constitute other desorption mechanisms.

- The redox potential of the medium. Sulfide oxidation mobilizes As only locally in sulfide-rich mining areas and under oxidizing conditions. Dissolved Fe tends to precipitate into ferric sulfate, oxides, and oxyhydroxide, with re-adsorption and co-precipitation of As; pyrite oxidation is not considered the most efficient mechanism in terms of As mobilization (Lillo, 2008).

- $\quad$ The $\mathrm{pH}$ of the solution. As is mobilized at $\mathrm{pH}$ values of groundwater in the range 6.5-8.5 (Lillo, 2008); adsorbs very strongly to the surfaces of iron oxides in acidic waters or with a neutral $\mathrm{pH}$ and desorbs when the $\mathrm{pH}$ becomes alkaline. This process, being one of the most effective mechanisms in its mobilization, is accompanied with a positive correlation between the As concentration in the aqueous phase and the $\mathrm{pH}$ (Mejía, González, Briones, Cardona, \& Soto, 2014). Alkalinization of the soil contributes to the mobility of As (Moreno, 2003), and diagenetic processes enhance the evolution of groundwater towards alkaline conditions leading to the desorption of As (Lillo, 2008).

- Competition for adsorption sites. Bicarbonate ion displaces arsenites and arsenates adsorbed on ferrihydrite (Mayorga, 2013), and overexploitation of aquifers mobilizes As.

- Microbiological activity. The microorganisms reduce the insoluble $\mathrm{Fe}^{+3}$ from the solid phase to the soluble $\mathrm{Fe}^{+2}$ form, mobilizing and reducing $\mathrm{As}^{+5}$ to $\mathrm{As}^{+3}$ (Mayorga, 2013).

- $\quad$ Presence of organic matter. There are bacteria that oxidize organic matter through the consumption of nitrates and in turn oxidize soluble $\mathrm{Fe}$ and $\mathrm{As}$ to respectively $\mathrm{Fe}^{+3}, \mathrm{Fe}^{+4}$ and $\mathrm{As}^{+5}$ (Machado, Bühl, \& Mañay, 2019). Furthermore, fulvic and humic acids compete for the adsorption sites of As in iron minerals (hematites) (Mayorga, 2013).

\section{Toxicology of As}

The half-life time of inorganic As in human's is 10 hours. Its biotransformation involves the reduction of As to acidic metabolites that are efficiently excreted; and continuous exposure results into the accumulation in certain tissues, affecting NADH (nicotinamide adenine dinucleotide) (Moreno, 2003), DNA (WHO, 2018; Markowski, Currie, Reeve, \& Thompson, 2010), and increasing the risk for the development of type II diabetes (Arias, 2016). WHO estimates that for As to be harmful an exposure of 5 to 10 years is required depending on the concentration, and estimates that more than 30 million people consume water with an As content above the permissible limit (WHO, 2018). 


\subsection{General objective}

The study contributes to the existing knowledge of the quality of water destined for human consumption by searching for toxic substances, such as arsenic, whose presence represents a danger to the health of the people that consumes water without prior treatment. In particular, the study aimed the development of a database of arsenic levels in selected water sources in the Ecuadorian cities Cuenca and Azogues to know their contamination level, define the relationship between As levels and physicochemical quality parameters, and analyze As contamination risk situations in groundwater and contaminated surface water sources.

\section{MATERIALS AND METHODS}

\subsection{Identification of monitoring stations}

The study consisted of specific actions in four rivers crossing the city of Cuenca, in the Quimsacocha páramos, irrigation wells of the University of Cuenca, and in the Burgay and Tabacay rivers of the city of Azogues. All these water sources are representative for the water used in the local water distribution system. For the assessment of the river water, stations were selected that allow interpreting the quality along the course of the rivers, starting in the high areas with little urban and industrial influence, passing through highly populated areas to finally form the Cuenca River, an important tributary of the Paute River, the hydrographic artery in the south of Ecuador. The monitoring points are identified as: Rio Tomebamba TO with 7 stations; River Yanuncay $\mathbf{Y}$ with 7; Río Tarqui TA with 7 stations; Río Machángara MA with 5; the parámos of Quimsacocha $\mathbf{Q}$ with 2 points; 5 groundwater wells W; Río Burgay $\mathbf{B}$ with 6; and the Río Tabacay TB with 6 stations. A total of 90 samples were analyzed spread over two campaigns in the period AugustNovember 2017.

\subsection{Methodology for water quality determination}

For the determination of the $\mathrm{pH}$, conductivity, apparent and real color, and turbidity we used the methods published in the $22^{\text {nd }}$ Edition of the Standard Methods for the evaluation of Water and Wastewater (American Water Works Association, 2012), and for the determination of the As concentration the Arsenator Wagtech Palintest Model WAG-WE1000143 instrument was used. To check the results, double samples were analyzed by the Silver Diethyldithiocarbamate (SDDC) method .

\subsection{Regulations pertaining to water use}

Specifications of the quality of water sources for respectively human and domestic consumption is 0,01 $\mathrm{mg} / \mathrm{L}$, the preservation of aquatic life $0.05 \mathrm{mg} / \mathrm{L}$, for irrigation water $0.1 \mathrm{mg} / \mathrm{l}$, livestock use $0.2 \mathrm{mg} / \mathrm{L}$, and for groundwater $0.035 \mathrm{mg} / \mathrm{L}$ (TULSMA, 2009) (see Ecuadorian TULSMA Regulations, Special Edition No. 387 GOB.EC (2015), BOOK VI, ANNEX 1).

\subsection{Methodology for predicting toxicological risk}

The used approach is based on Pauta (2014) and consists of mathematical calculations for the prediction of the chronic effect that would be produced by continuous ingestion of a contaminant.

\section{Cancer risk index}

The probability that cancer occurs as a consequence of exposure to a pollutant (Moreno, 2003) is calculated with the following equation:

Cancer risk $=\frac{L A D D * \text { slope factor }}{\text { Allowed dose for a given risk }}($ Equation 1$)$

where LADD stands for the lifetime average daily dose, it is the daily dose of the toxic element that a person would receive throughout his life if the exposure were continuous at a given concentration. The latter is calculated using Equation 2:

$L A D D=\frac{C T * T C * B * P E * F E}{P C * 70 * 365}$

(Equation 2)

where $\mathrm{CT}$ is the concentration in water of the toxic substance $(\mathrm{mg} / \mathrm{L})$; TC the contact rate equal to $2 \mathrm{~L} /$ personday (EPA); B the bioavailability ( 0.7 for As in drinking water); $\mathrm{PE}$ the exposure period in years; $\mathrm{FE}$ the frequency of exposure in days/year; and PC the body weight in $\mathrm{kg} /$ person. The slope factor in Equation 1 represents the relationship between the dose of carcinogen and the incidence of tumors (Moreno, 2003), while the permitted daily dose for a given risk stands for the intake of As in water for a risk of $1 \mathrm{E}^{-6}$ (the possibility that a person per million contracts cancer), which can be calculated by Equation 3:

$$
\text { Permitted dose }=\frac{\text { Permitted concentration } * T C}{P C \quad}
$$

where the permitted daily dose $=2 \mathrm{E}^{-5} \mathrm{mg} \mathrm{As} / \mathrm{L} * 2$ $\mathrm{L} /$ person-day-70 $\mathrm{kg}$ person $=5.71 \mathrm{E}^{-7} \mathrm{mg} / \mathrm{day}-\mathrm{kg}$. If the calculated risk is $>1$ means that the probability of developing cancer is greater than that calculated for a unit per million inhabitants.

\section{Criteria for calculating the toxicological risk}

To calculate the risk to which humans are exposed by the continuous consumption (for a period of 25 years) of water contaminated with As, it is considered that the route of exposure to the poison involves direct contact, from the source to the human organism and taking as a reference EPA toxicological data and the Toxicological Databases: Weight of Evidence $(\mathrm{WoE})=1 \mathrm{~A}$; Oral Slope Factor $=1.5$ $\mathrm{mg} / \mathrm{kg}$-day; risk level $=1 \mathrm{E}^{-6}(1$ of every million inhabitants); and permitted concentration for this risk level $=2 \mathrm{E}^{-5} \mathrm{mg}$ As/L.

\section{RESULTS}

Table 1 presents the results of the water quality in the two hydrological periods of monitoring, and Table 2 shows the results of the Cancer Risk Index for the As concentration 
in the last monitoring station of the Tomebamba river applying Equation 1. The cancer risk index is $>1$, only in the last station of the Tomebamba river with a value of 1.36. This means that if the water were consumed without prior treatment for 25 years, not just one person would get cancer in a million population but 1.36 people. In the other stations, the index is less than 1.

\section{STATISTICAL ANALYSIS AND DISCUSSION}

The statistical interpretation of the registered As levels for different flow rates is shown in Table 3. The Machangara and Tarqui rivers do not register As values in the low flow regime $\left(\mathrm{LF}^{1}\right)$ but the toxic substance is detected in the high flow regime $\left(\mathrm{HF}^{1}\right)$. The average levels present a high variability between the separate places, as depicted in Figure 1. During HF was the highest average value found in the Burgay river $(6.8 \mu \mathrm{g} / \mathrm{L})$, and the highest maximum value in the Tomebamba river $(28 \mu \mathrm{g} / \mathrm{L})$. In the dry season (LF), the highest average value was for the Yanuncay river $(6.6 \mu \mathrm{g} / \mathrm{L})$, and the maximum concentration of As was found in the Tomebamba river $(8 \mu \mathrm{g} / \mathrm{L})$. The statistical behavior reflected the absence of normality, justifying the use of the Shapiro Wilk test which is significant in all observed cases $(p<0.05)$, and permitting the application of nonparametric statistics such as the percentiles and the Spearman rank correlation test.

The level of As during HF in the Tomebamba river varies statistically from 0 to $28 \mu \mathrm{g} / \mathrm{L}$, the latter being the highest observed level which exceeds the reference norm of 10 $\mu \mathrm{g} / \mathrm{L}$ for human consumption. On the other hand, during LF the maximum levels that occur in the Tomebamba and Burgay rivers, respectively 8 and $6.6 \mu \mathrm{g} / \mathrm{L}$, do not exceed the reference norm. The intervals that allow determining the parameter of As in each place are smaller during HF, which would imply in general lower levels of As during LF.

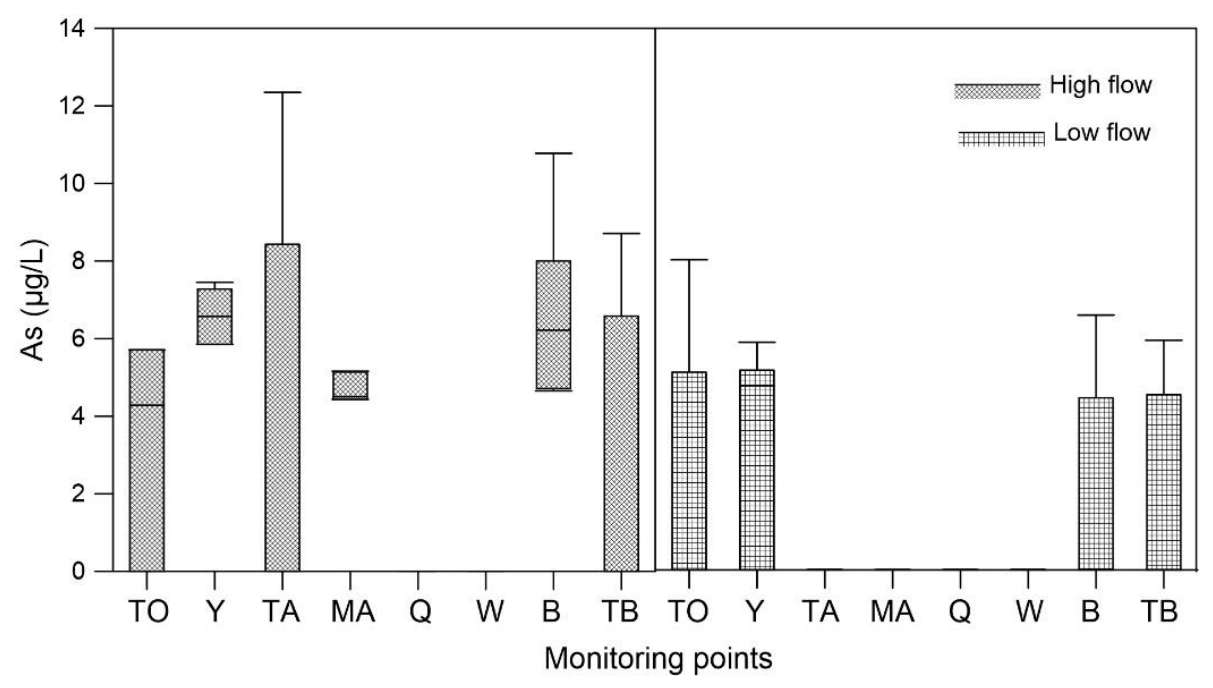

Figure 1. The behavior of As $(\mu \mathrm{g} / \mathrm{L})$ in two seasons of the year.

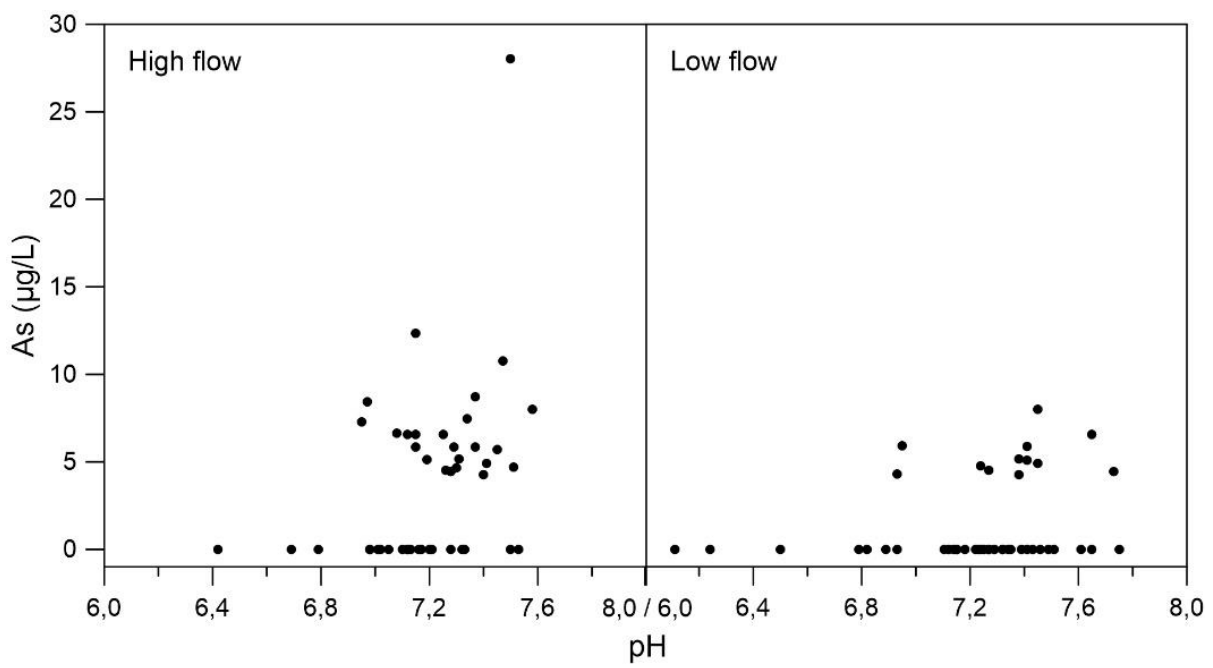

Figure 2. The behavior of As $(\mu \mathrm{g} / \mathrm{L})$ in two seasons of the year as a function of $\mathrm{pH}$.

${ }^{1}$ LF = Low Flow; HF = High Flow 
Table 1. Water quality data measured during period of low flow (LF) and high flow (HF).

\begin{tabular}{|c|c|c|c|c|c|c|c|c|c|c|c|c|c|c|}
\hline \multirow[t]{2}{*}{ Tomebamba River } & \multicolumn{7}{|c|}{ Low Flow: $14^{\text {th }}$ of August 2017} & \multicolumn{7}{|c|}{ High Flow: $27^{\text {th }}$ of October 2017} \\
\hline & TO1 & TO2 & TO3 & TO4 & TO5 & TO6 & TO7 & TO1 & TO2 & TO3 & TO4 & TO5 & TO6 & TO7 \\
\hline $\mathrm{pH}$ & 6.9 & 7.2 & 7.3 & 7.2 & 7.5 & 7.4 & 7.4 & 7.1 & 7.2 & 7.3 & 7.4 & 7.5 & 7.5 & 7.4 \\
\hline Temperature $\left({ }^{\circ} \mathrm{C}\right)$ & 14.8 & 14.2 & 14.4 & 14.5 & 14.7 & 14.4 & 14.3 & 12.5 & 14.0 & 15.1 & 15.6 & 15.8 & 15.1 & 15.7 \\
\hline Conductivity $(\mu \mathrm{s} / \mathrm{cm})$ & 108.5 & 120.2 & 136.2 & 154.9 & 180.7 & 156.9 & 211.0 & 128.1 & 113.4 & 120.9 & 129.4 & 155.1 & 142.0 & 179.0 \\
\hline Turbidity (ntu) & 1.5 & 1.5 & 1.4 & 6.2 & 8.6 & 2.3 & 28.3 & 1.3 & 1.9 & 7.9 & 8.9 & 11.9 & 222.0 & 26.7 \\
\hline Color (500 Pt Co) & 52.0 & 57.0 & 62.0 & 72.0 & 80.0 & 87.0 & 142.0 & 57.0 & 61.0 & 63.0 & 71.0 & 86.0 & 1240.0 & 135.0 \\
\hline Arsenic $(\mu \mathrm{g} / \mathrm{L})$ & 0.0 & 0.0 & 0.0 & 0.0 & 8.00 & 4.28 & 5.10 & 0.0 & 0.0 & 0.0 & 4.28 & 5.71 & 28.04 & 4.90 \\
\hline \multirow[t]{2}{*}{ Yanuncay River } & \multicolumn{7}{|c|}{ Low Flow: $15^{\text {th }}$ of August 2017} & \multicolumn{7}{|c|}{ High Flow: $30^{\text {th }}$ of October 2017} \\
\hline & $\mathrm{Y} 1$ & $\mathrm{Y} 2$ & Y3 & Y4 & Y5 & Y6 & $\mathrm{Y} 7$ & $\mathrm{Y} 1$ & $\mathrm{Y} 2$ & Y3 & Y4 & Y5 & Y6 & Y7 \\
\hline $\mathrm{pH}$ & 7.5 & 7.5 & 7.1 & 7.4 & 7.3 & 7.5 & 7.4 & 7.3 & 7.4 & 7.2 & 7.1 & 7.2 & 7.0 & 7.1 \\
\hline Temperature $\left({ }^{\circ} \mathrm{C}\right)$ & 15.6 & 15.5 & 16.0 & 16.1 & 16.0 & 15.9 & 15.7 & 12.3 & 12.4 & 12.9 & 13.2 & 13.1 & 13.4 & 14.6 \\
\hline Conductivity $(\mu \mathrm{s} / \mathrm{cm})$ & 102.8 & 95.8 & 104.1 & 144.6 & 127.5 & 145.2 & 186.0 & 53.7 & 54.0 & 56.5 & 70.3 & 64.8 & 69.9 & 112.8 \\
\hline Turbidity (ntu) & 2.9 & 1.9 & 3.1 & 4.0 & 9.8 & 7.8 & 17.1 & 2.5 & 3.2 & 3.5 & 6.9 & 7.4 & 11.5 & 68.2 \\
\hline Color (500 Pt Co) & 45.0 & 32.0 & 61.0 & 73.0 & 84.0 & 77.0 & 95.0 & 54.0 & 64.0 & 61.0 & 84.0 & 82.0 & 104.0 & 314.0 \\
\hline Arsenic $(\mu \mathrm{g} / \mathrm{L})$ & 4.30 & 0.00 & 0.00 & 4.75 & 4.90 & 5.15 & 5.87 & 7.45 & 5.85 & 0.0 & 6.57 & 5.85 & 7.28 & 6.65 \\
\hline \multirow[t]{2}{*}{ Tarqui River } & \multicolumn{7}{|c|}{ Low Flow: $17^{\text {th }}$ of August 2017} & \multicolumn{7}{|c|}{ High Flow: $1^{\text {st }}$ of November 2017} \\
\hline & TA1 & TA2 & TA3 & TA4 & TA5 & TA6 & TA7 & TA1 & TA2 & TA3 & TA4 & TA5 & TA6 & TA7 \\
\hline $\mathrm{pH}$ & 7.2 & 7.3 & 7.2 & 7.1 & 7.3 & 7.7 & 7.5 & 7.1 & 7.12 & 7.5 & 7.01 & 6.98 & 7.15 & 6.97 \\
\hline Temperature $\left({ }^{\circ} \mathrm{C}\right)$ & 15.3 & 15.8 & 16.1 & 16.2 & 16.2 & 15.6 & 15.9 & 13.8 & 14.7 & 15.1 & 15.3 & 14.7 & 14.4 & 14.7 \\
\hline Conductivity $(\mu \mathrm{s} / \mathrm{cm})$ & 58.9 & 124.9 & 135.1 & 140.5 & 130.8 & 130.3 & 179.5 & 45.6 & 105.6 & 104.6 & 122.1 & 87.2 & 89.4 & 120.0 \\
\hline Turbidity (ntu) & 4.5 & 12.5 & 11.2 & 11.8 & 65.3 & 61.1 & 26.2 & 16.0 & 39.5 & 59.9 & 89.6 & 89.5 & 92.7 & 96.1 \\
\hline Color (500 Pt Co) & 86.0 & 120.0 & 130.0 & 98.0 & 493.0 & 461.0 & 174.0 & 132.0 & 231.0 & 338.0 & 451.0 & 452.0 & 465.0 & 468.0 \\
\hline Arsenic $(\mu \mathrm{g} / \mathrm{L})$ & 0.0 & 0.0 & 0.0 & 0.0 & 0.0 & 0.0 & 0.0 & 0.0 & 0.0 & 0.0 & 0.0 & 0.0 & 12.35 & 8.43 \\
\hline \multirow[t]{2}{*}{ Machángara River } & \multicolumn{7}{|c|}{ Low Flow: $18^{\text {th }}$ of August 2017} & \multicolumn{7}{|c|}{ High Flow: $2^{\text {nd }}$ of November 2017} \\
\hline & MA1 & MA2 & MA3 & MA4 & MA5 & & & MA1 & MA2 & MA3 & MA4 & MA5 & & \\
\hline $\mathrm{pH}$ & 7.1 & 7.4 & 7.4 & 7.4 & 7.3 & & & 7.2 & 7.2 & 7.3 & 7.3 & 7.3 & & \\
\hline Temperature $\left({ }^{\circ} \mathrm{C}\right)$ & 15.2 & 15.1 & 15.0 & 15.0 & 14.8 & & & 12.5 & 12.9 & 13.1 & 13.3 & 13.8 & & \\
\hline Conductivity $(\mu \mathrm{s} / \mathrm{cm})$ & 89.0 & 99.9 & 101.0 & 110.7 & 116.8 & & & 95.4 & 101.0 & 103.9 & 107.8 & 126.1 & & \\
\hline Turbidity (ntu) & 2.5 & 3.2 & 3.7 & 5.1 & 8.9 & & & 4.6 & 4.9 & 5.7 & 7.7 & 16.5 & & \\
\hline Color (500 Pt Co) & 56.0 & 82.0 & 57.0 & 85.0 & 102.0 & & & 42.0 & 49.0 & 52.0 & 53.0 & 76.0 & & \\
\hline Arsenic $(\mu \mathrm{g} / \mathrm{L})$ & 0.0 & 0.0 & 0.0 & 0.0 & 0.0 & & & 0.0 & 5.14 & 5.16 & 4.43 & 4.50 & & \\
\hline
\end{tabular}


Table 1. Water quality data measured during period of low flow (LF) and high flow (HF) (continued).

\begin{tabular}{|c|c|c|c|c|c|c|c|c|c|c|c|c|}
\hline \multirow[t]{2}{*}{ Burgay River } & \multicolumn{6}{|c|}{ Low Flow: $19^{\text {th }}$ of August 2017} & \multicolumn{6}{|c|}{ High Flow: $28^{\text {th }}$ of October 2017} \\
\hline & B1 & B2 & B3 & B4 & B5 & B6 & B1 & B2 & B3 & B4 & B5 & B6 \\
\hline $\mathrm{pH}$ & 7.8 & 7.7 & 7.3 & 7.7 & 7.5 & 7.6 & 7.3 & 7.5 & 7.3 & 7.6 & 7.3 & 7.5 \\
\hline Temperature $\left({ }^{\circ} \mathrm{C}\right)$ & 14.9 & 15.5 & 15.8 & 16.3 & 16.5 & 16.7 & 12.5 & 12.7 & 13.1 & 13.6 & 13.9 & 14.2 \\
\hline Conductivity $(\mu \mathrm{s} / \mathrm{cm})$ & 126.6 & 156.5 & 627.0 & 430.0 & 647.0 & 646.0 & 103.8 & 121.6 & 465.0 & 307.0 & 515.0 & 508.0 \\
\hline Turbidity (ntu) & 2.8 & 3.5 & 34.6 & 14.5 & 75.1 & 56.8 & 2.3 & 25.2 & 70.4 & 67.5 & 187.0 & 109.0 \\
\hline Color (500 Pt Co) & 45.0 & 33.0 & 185.0 & 115.0 & 335.0 & 245.0 & 52.0 & 144.0 & 245.0 & 265.0 & 650.0 & 307.0 \\
\hline Arsenic $(\mu \mathrm{g} / \mathrm{L})$ & 0.0 & 6.57 & 0.0 & 4.44 & 0.0 & 0.0 & 5.86 & 10.78 & 4.65 & 8.00 & 6.57 & 4.71 \\
\hline \multirow[t]{2}{*}{ Tabacay River } & \multicolumn{6}{|c|}{ Low Flow: $19^{\text {th }}$ of August 2017} & \multicolumn{6}{|c|}{ High Flow: $11^{\text {th }}$ of November 2017} \\
\hline & TB1 & TB2 & TB3 & TB4 & TB5 & TB6 & TB1 & TB2 & TB3 & TB4 & TB5 & TB6 \\
\hline $\mathrm{pH}$ & 6.2 & 7.1 & 7.2 & 7.4 & 7.3 & 7.0 & 6.4 & 6.8 & 7.0 & 7.1 & 7.4 & 7.2 \\
\hline Temperature $\left({ }^{\circ} \mathrm{C}\right)$ & 19.1 & 19.1 & 19.5 & 19.4 & 19.2 & 19.5 & 18.5 & 18.7 & 18.7 & 18.9 & 19.1 & 19.2 \\
\hline Conductivity $(\mu \mathrm{s} / \mathrm{cm})$ & 260.0 & 309.0 & 378.0 & 475.0 & 1207.0 & 320.0 & 360.0 & 416.0 & 487.0 & 545.0 & 1498.0 & 452.0 \\
\hline Turbidity (ntu) & 8.1 & 62.1 & 36.6 & 29.6 & 45.5 & 11.6 & 10.5 & 89.6 & 50.8 & 49.7 & 79.4 & 28.4 \\
\hline Color (500 Pt Co) & 79.0 & 303.0 & 186.0 & 179.0 & 236.0 & 77.0 & 89.0 & 467.0 & 274.0 & 263.0 & 419.0 & 92.0 \\
\hline $\operatorname{Arsenic}(\mu \mathrm{g} / \mathrm{L})$ & 0.0 & 0.0 & 0.0 & 0.0 & 4.52 & 5.92 & 0.0 & 0.0 & 0.0 & 0.0 & 8.71 & 6.58 \\
\hline \multirow[t]{2}{*}{ Quimsacocha River } & \multirow{2}{*}{\multicolumn{6}{|c|}{ Low Flow: $15^{\text {th }}$ of August 2017}} & \multicolumn{6}{|c|}{ High Flow: $27^{\text {th }}$ of October 2017} \\
\hline & & & & & & & Q1 & Q2 & & & & \\
\hline $\mathrm{pH}$ & 7.3 & 7.5 & & & & & 7.3 & 7.5 & & & & \\
\hline Temperature $\left({ }^{\circ} \mathrm{C}\right)$ & 15.8 & 16.1 & & & & & 17.9 & 17.7 & & & & \\
\hline Conductivity $(\mu \mathrm{s} / \mathrm{cm})$ & 80.6 & 41.2 & & & & & 39.8 & 44.0 & & & & \\
\hline Turbidity (ntu) & 1.0 & 1.5 & & & & & 1.5 & 10.2 & & & & \\
\hline Color (500 Pt Co) & 30.0 & 47.0 & & & & & 52.0 & 74.0 & & & & \\
\hline Arsenic $(\mu \mathrm{g} / \mathrm{L})$ & 0.0 & 0.0 & & & & & 0.0 & 0.0 & & & & \\
\hline \multirow[t]{2}{*}{ Wells } & \multicolumn{6}{|c|}{ Low Flow: $20^{\text {th }}$ of October 2017} & \multicolumn{6}{|c|}{ High Flow: $14^{\text {th }}$ of November 2017} \\
\hline & $\mathrm{P} 1$ & $\mathrm{P} 2$ & P3 & P4 & P5 & & $\mathrm{P} 1$ & $\mathrm{P} 2$ & P3 & P4 & P5 & \\
\hline $\mathrm{pH}$ & 6.8 & 6.5 & 6.8 & 6.9 & 6.1 & & 7.0 & 7.1 & 7.3 & 6.7 & 7.2 & \\
\hline Temperature $\left({ }^{\circ} \mathrm{C}\right)$ & 16.8 & 17.1 & 17.5 & 17.0 & 17.9 & & 17.6 & 17.5 & 18.2 & 18.3 & 18.1 & \\
\hline Conductivity $(\mu \mathrm{s} / \mathrm{cm})$ & 161.1 & 393.0 & 501.0 & 514.0 & 413.0 & & 263.0 & 641.0 & 517.0 & 579.0 & 398.0 & \\
\hline Turbidity (ntu) & 9.7 & 1.3 & 2.3 & 1.1 & 1.0 & & 4.2 & 12.9 & 2.4 & 1.0 & 0.6 & \\
\hline Color (500 Pt Co) & 29.0 & 11.0 & 17.0 & 4.0 & 2.0 & & 12.0 & 53.0 & 16.0 & 5.0 & 2.0 & \\
\hline Arsenic $(\mu \mathrm{g} / \mathrm{L})$ & 0.0 & 0.0 & 0.0 & 0.0 & 0.0 & & 0.0 & 0.0 & 0.0 & 0.0 & 0.0 & \\
\hline
\end{tabular}


Table 2. Calculation of the Cancer Risk Index.

\begin{tabular}{ll}
\hline Data for calculating the Cancer Risk index & Value \\
\hline As concentration $(\mathrm{mg} / \mathrm{L})$ & 0.0283 \\
Upper confidence limit concentration $(95 \%)$ & 0.027 \\
LADD (mg/kg-day) & $5.20 \mathrm{E}-07$ \\
Slope factor (mg/kg-day) & 1.5 \\
Weight of evidence & $1 \mathrm{~A}$ \\
Permitted concentration for a given risk & $2.00 \mathrm{E}-05$ \\
Permitted dose (mg/kg-day) & $5.70 \mathrm{E}-07$ \\
Permitted concentration for a 1-in-1 million cancer risk & $1.00 \mathrm{E}-06$ \\
Cancer Risk index & 1.36 \\
\hline
\end{tabular}

Table 3. Arsenic levels $(\mu \mathrm{g} / \mathrm{L})$ recorded in the two different flow rates.

\begin{tabular}{lccccccccccc}
\hline River & \multicolumn{2}{c}{ Average } & \multicolumn{2}{c}{ Standard error } & \multicolumn{2}{c}{ Median } & \multicolumn{2}{c}{ Minimum } & \multicolumn{2}{c}{ Maximum } \\
\hline Discharge & High & Low & High & Low & High & Low & High & Low & High & Low \\
\hline Tomebamba & 6.1 & 2.5 & 3.8 & 1.3 & 4.3 & 0 & 0 & 0 & 28 & 8 \\
Yanuncay & 5.7 & 3.6 & 0.97 & 0.94 & 6.6 & 4.8 & 0 & 0 & 7.5 & 5.9 \\
Machángara & 3.9 & - & 0.97 & - & 4.5 & - & 0 & - & 5.2 & - \\
Tarqui & 3 & - & 2 & - & 0 & - & 0 & - & 12 & - \\
Parámos & - & - & - & - & - & - & - & - & - & - \\
Wells & - & - & - & - & - & - & - & - & - & - \\
Burgay & 6.8 & 1.8 & 0.95 & 1.2 & 6.2 & 0 & 4.7 & 0 & 11 & 6.6 \\
Tabacay & 2.6 & 1.7 & 1.6 & 1.1 & 0 & 0 & 0 & 0 & 8.7 & 5.9 \\
\hline Total & 4 & 1.4 & 0.76 & 0.36 & 4.4 & 0 & 0 & 0 & 28 & 8 \\
\hline
\end{tabular}

A high positive and significant correlation between As levels and the physical-chemical quality parameters of water is observed during HF; according to the Spearman statistics $(p<0.05)$ between As and $\mathrm{pH}$. The correlations between turbidity, color, and temperature with the As level are also high $(p<0.05)$. Electrical conductivity did not show a statistical relationship with As. During LF was a high, positive, and significant correlation $(p<0.05)$ observed between the As- and $\mathrm{pH}-$ level, less strong than during LF (Figure 2). The correlations between turbidity, color temperature, and electrical conductivity with the level of As $(p>0.05)$ are not significant during LF, but significant during HF.

The concentration of As is higher during HF, because typical in high mountain rivers are sediments and colloidal material transported during intense precipitation events, a process favored with the increase in $\mathrm{pH}$ (COPEA, 2014). Later when the flow decreases are the particles deposited or when they are co-precipitated with iron oxide. However, another study (García et al., 2011) shows that in the rainy season the concentration of As in the river water decreases due to dilution and that the concentration of As is higher on the sediments. The $\mathrm{pH}$ in rivers ranges between 6.2 and 7.7 and represents oxidized conditions. If this interval is transferred to the $\mathrm{Eh} / \mathrm{pH}$ diagram, it shows the zone where $\left(\mathrm{HAsO}_{4}\right)^{2-}$ is predominant present with a high probability to be retained in the solid phase by metallic oxides, clays, etc. As stated by Calvo Revuelta, Álvarez-Benedí, Andrade Benítez, Marinero Diez, \& Bolado Rodríguez (2003) is the concentration of As in rivers regulated by adsorption-desorption processes responsible for the solubilization or retention of As on sediments. Another study shows that As dissolves in alkaline river water, confirming the relationship of As concentration with $\mathrm{pH}$ (Richter et al., 2019). In the present study contained the analyzed groundwater samples hardly As, but this might be different in other aquifers due to the flow regime and mineralogical composition of the aquifer (Calvo Revuelta et al., 2019). Risk of As contamination in páramos should be avoided at all times, since studies showed that mining, such as the "Loma Larga" project, leads to an accumulation of toxic substances in the soil and groundwater, particularly in periods of low precipitation levels. It is also mentioned that the Kori Kollo páramo (Bolivia) generates for the same reason As effluents (Pesántez, 2017). Open mining can affect in two ways, namely the sulfide-based oxidation products that accumulate on the rock surfaces in combination with heavy rainfall produces "acid mine runoff" and leakage of alkaline wastewater rich in cyanide, resulting in high concentrations of As (COPEA, 2014).

\section{CONCLUSIONS}

The study reveals that groundwater and páramos in the studied region are free of As, and it is most appropriate to maintain the conservation state of these ecosystems. The As level in all rivers is tolerable, affected by the hydrologic regime at the moment of sampling. For example, the As level in the water of the Machángara and Tarqui rivers is low during low flow regime, but present in the winter season when the flow regime of the rivers is high. Arsenic in the surface water comes from agricultural pesticides and is less likely to be of industrial origin. Agriculture is the main activity in all studied basins responsible for diffuse pollution, a process difficult to control. The dominant form of arsenic is $\mathrm{As}^{+5}$, according to Castro (2004) the least toxic, possessing a large adsorption capacity on mineral surfaces. The concentration of As is $\mathrm{pH}$ related, higher in winter, and the $\mathrm{pH}$ favors the As precipitation or desorption from the sediments. The color and turbidity of the surface water are positively affected by As, and both turn out to be a good indicator of the toxicity of the water, useful tools for the water management boards to decide if the use of the water resource should be limited. An increase in the $\mathrm{pH}$ enhances the desorption of As from mineral surfaces, while an increase in the $\mathrm{pH}$ promotes the dissolution of 
iron minerals releasing As. Both these scenarios became clear from mining (Castro, 2004), and are exaggerated by an increase in the exploitation of aquifers that modifies the redox potential of the environment. The study has shown that the analyzed water bodies, with the exception of one station, do not pose a "cancer risk", and there is also no risk to the ecosystem. However, under certain conditions the As concentration might reach a worrying level.

\section{RECOMMENDATIONS}

The presence of carcinogenic elements in rivers require permanent monitoring of the water quality. In addition, knowledge of the hydrogeochemical reactions governed by the redox potential (Eh), the $\mathrm{pH}$, or the presence of other elements is important to establish the contamination risk of As. Furthermore, given the high As concentration of $438.8 \mu \mathrm{g} / \mathrm{L}$ found in the Spa of Baños, situated in the parish with the same name, of geochemical origin in combination with the hydrothermal treatment of the water urges to consider the natural presence of As associated with tertiary and quaternary volcanism in the Cordillera de Los Andes. In addition, to the analysis of river water samples, it is recommended to also monitor the presence of As on the sediments in the rivers. Given the increasing demand for water and the search for new sources to satisfy the demand, this study reveals that investigations should include hydrochemical analyses to guarantee the safe exploitation of the water sources.

\section{REFERENCES}

Arias, M. C. (2016). Polimorfismo rs699780 del gen NOTCH2 como factor proinflamatorio y su asociación con diabetes tipo 2 en sujetos expuestos a agua contaminada con arsénico. Tesis de maestría en Ciencias de la Salud. Durango, México: Facultad de Medicina y Nutrición, Universidad Juárez del Estado de Durango.

Bundschub, J. Pérez, A., \& Litter, M. (2008). Distribución del arsénico en las regiones Ibérica e Iberoamericana. Buenos Aires, Argentina: Editorial CYTED.

Calvo Revuelta, C., Álvarez-Benedí, J., Andrade Benítez, M., Marinero Diez, P., \& Bolado Rodríguez, S. (2003). Contaminación por arsénico en aguas subterráneas en la provincia de Valladolid: Variaciones estacionales. Estudios de la Zona No Saturada del Suelo, Vol. VI., pp. 8. Available at http://www.zonanosaturada.com/zns03/publications_fil es/p091-098.pdf.

Carbantes, A., \& De Fernicola, N. (2003). Arsénico en el agua de bebida: un problema de salud pública. Revista Brasileira de Ciencias Farmacéuticas, 39(4), 365-372.

Castro, M. L. (2004). Presencia de arsénico en el agua de bebida en América Latina y su efecto en la salud pública. HDT - CEPIS N 95, 12 p. Available at ingenieroambiental.com/4014/hdt95.pdf

COPEA. (2014). El impacto de la minería canadiense en América Latina y la responsabilidad de Canadá. pp. 126. Available at
http://www.copaeguatemala.org/pdf/informes/Sedimen tos.pdf

Delgado, J., Medina, J., Vega, M., Carretero, C., \& Pardo, R. (2009). Los minerales de la arcilla y el arsénico en los acuíferos de la Tierra de Pinares, Valladolid. Revista de la Sociedad Española de Mineralogía (Macla), 11; 75-76.

ELIKA. (2013). Arsénico. España: Fundación Vasca para la seguridad agroalimentaria. Available at https://seguridadalimentaria.elika.eus/wpcontent/uploads/2018/01/27.Ars\%C3\%A9nico.pdf

Galindo, G., Fernández, J., Parada, M., \& Gimeno, D. (2005). Arsénico en aguas: origen, movilidad y tratamiento. Rio Cuarto, Argentina: IV Congreso Hidrogeologico. Available at https://digital.csic.es/ bitstream/10261/4019/1/Galindo_et_al-Arsenico2005.pdf

García, E., Carrizales, L., Juárez, L., García, E., Hernández, E., Briones, E., \& Vázquez, O. (2011). Plomo y arsénico en la subcuenca del Alto Atoyac en Tlaxcala, México. Revista Chapingo, Serie Ciencias Forestales y del Ambiente, 17(1), 7-17. https://doi.org/10.5154/r.rchscfa.2010.06.040

Genc, H., Tjell, J. C., McConchie, D., \& Schuilling, O. (2003). Adsorption of arsenate from water using neutralized red mud. Journal of Colloid and Interface Science, 264(2), 327-334. https://doi.org/10.1016/S0021-9797(03)00447-8

González-Váldez, L., Quintos-Escalante, M., ReyesNavarrete, M.-G. R., Alarcón, E. C. V., Alvarado, A.I., Antuna, D.-M., García-Vargas, A., Jaques-Matas, V., \& Orona-Meza, F. (2011). Efectos a la salud por la ingesta crónica de arsénico en agua. Vidsupra: Visión Científica, 3(2), 24-28.

IARC. (2018). Agents Classified by the IARC Monographs, Volumes 1-12. International Agency for Research on Cancer. Available at https://monographs.iarc.fr/agents-classified-by-theiarc/

Lillo, J. (2008). Peligros geoquímicos: arsénico de origen natural en las aguas. GEMM, 2-3, 33.

Machado, I., Bühl, V., Mañay, N. (2019). Total arsenic and inorganic arsenic speciation in groundwater intended for human consumption in Uruguay: Correlation with fluoride, iron, manganese and sulfate. Journal Science of the Total Environment, 681(1), $497-$ 502. https://doi.org/10.1016/j.scitotenv.2019.05.107

Mañay, N., Pistón, M., Cáceres, M., Pizzorno, P., \& Bühl, V. (2019). An overview of environmental arsenic issues and exposure risks in Uruguay. Journal Science of the Total Environment, 686, 590-598. https://doi.org/10.1016/j.scitotenv.2019.05.443

Markowski, V. P., Currie, D., Reeve, E. A., Thompson, D., \& Wise, J. P. (2010). Tissue-specific and doserelated accumulation of arsenic in mouse offspring following maternal consumption of arseniccontaminated water. Basic \& Clinical Pharmacology \& Toxicology, 108, 326-332. https://doi.org/10.1111/j.1742-7843.2010.00660.x

Mayorga, M. (2013). Arsénico en aguas subterráneas su transferencia al suelo y a la planta. Tesis doctoral. Universidad de Valladolid. Escuela Universitaria Ingenierías Agrarias, Departamento Producción Vegetal y Recursos Forestales. Instituto de Recursos Naturales y Agrobiología de Salamanca-CSIC. pp. 59. 
Mejía, M., González, I., Briones, J., Cardona, A., \& Soto, P. (2014). Mecanismos que liberan arsénico al agua subterránea de la Comarca Lagunera, estados de Coahuila y Durango, México. Revista Tecnologías y Ciencias del Agua, 5(1), 71-82.

Moreno, M. D. (2003). Toxicología ambiental: Evaluación del riesgo para la salud humana. (1 $\left.{ }^{\mathrm{a}} \mathrm{ed}.\right)$. España: McGraw-Hill Interamericana de España.

Ng, J. C., Wang, J., \& Shraim, A. (2003). A global health problem caused by arsenic from natural sources. Chemosphere, 52(9), 1353-1359. https://doi.org/10.1016/S0045-6535(03)00470-3

Pauta, G. (2014). Estudio integral de la calidad de agua del Río Burgay, y evaluación del riesgo toxicológico por la probable presencia de plaguicidas. Tesis de Maestria en Toxicologia Industrial y Ambiental, Universidad de Cuenca. pp. 163. Available at http://dspace.ucuenca.edu.ec/handle/123456789/19831

Pesántez, C. (2017). Identificación del impacto producido por la minería en Quimsacocha en la recarga de aguas superficiales y subterráneas. Tesis de Pregrado, pp. 66. Universidad de Cuenca. Available at http://dspace.ucuenca.edu.ec/handle/ $123456789 / 28492$

Ramírez, A. V. (2013). Exposición ocupacional y ambiental al arsénico. Anales de la Facultad de Medicina, 47(3), 237-247.

Richter, L.,Hechavarría, A., Pessôa, G., Zezzi, M. A., Rezende-Filho, A. T., Bartimann, R., Menezes, H. A., Richter, L.,Hechavarría, A., Pessôa, G., Zezzi, M. A., Rezende-Filho, A. T., Bartimann, R., Menezes, H. A., Valles, V., Barbiero, L., \& Fostier, A-H. (2019). Dissolved arsenic in the upper Paraguay River basin and Pantanal wetlands. Journal Science of the Total Environment, 687, 919-928.

https://doi.org/10.1016/j.scitotenv.2019.06.147
Salomón, M., Guamán, C., Rubio, C., Galárraga, R., \& Abraham, E. (2008). Indicadores del uso del agua en una zona de los Andes Centrales de Ecuador. Estudio de la cuenca del Río Ambato. Ecosistemas, 17(1), 72-85.

Shi, F. (2004). Arsenic in groundwater in Huhhot alluvial basin in Inner Mongolia, Peoples Republic of China. Master thesis, pp. 57. Stockholm, Sweden: Royal Institute of Technology.

Souza, T. D., Borges, A. C., Braga, A. F., Veloso, R. W., \& Matos, A. T. (2019). Phytoremediation of arseniccontaminated water by Lemna Valdiviana: An optimization study. Chemosphere, 234, 402-408. https://doi.org/10.1016/j.chemosphere.2019.06.004

WHO. (2011). Arsenic in drinking-water. Guidelines for drinking-water quality. 24 p. Geneva, Switzerland: World Health Organization. Available at https://www.who.int/water_sanitation_ health/dwq/chemicals/arsenic.pdf

WHO. (2018). Arsenic. Available at https://www.who.int/news-room/factsheets/detail/arsenic 